ISSN: $1305-578 \mathrm{X}$

Journal of Language and Linguistic Studies, 16(2), 647-660; 2020

\title{
Existential negation in Turkish: A functional approach
}

\author{
Muberra Seydi a 1 (D) \\ ${ }^{a}$ Canada Foreign Service Institute, Ottawa/Gatineau, Canada
}

\section{APA Citation:}

Seydi, M. (2020) Existential negation in Turkish: A functional approach. Journal of Language and Linguistic Studies, 16(2), 647-660.

Submission Date:. 12 /09/2019

Acceptance Date:18/05/2020

\begin{abstract}
Existential negation is the one type of negation present in languages, which its item is called "negative existential", and it provides to tell the case of "absence", "lack", "there is not", "poor", "empty", "dead" etc. Negative existentials are generally used for the common similarity of a structure as morphological, syntactic and semantic typologies. In Turkish, existential negation occurs with the independent morpheme yok, which is defined as "absolute absence/non-existence". Yok is the main negative existential that is different from the standard negation and it is a separate lexical item with negative content. Since it is a powerful negator with its "absolute absence/nonexistence" meaning, it can be used in different positions, such as existential negation, possessive negation, emphatic negation, standard negation, short answer "no", prohibition or double negation. In addition to yok, the bound morpheme $-s X z$ is used with "without/lack" meaning in existential negation by implying the non-existence case. Besides, general rejection item değil, which means "is not", is used in existential negation, which implies the non-existentiality by rejecting the existence case that is presupposed.
\end{abstract}

(C) 2020 JLLS and the Authors - Published by JLLS.

Keywords: existential negation; turkish negative existentials; yok; -sXz; değil.

\section{Introduction}

Negation has some type of complex structures in languages which tells the truth of affirmation. As it is known, affirmation is the priority in languages and structurally, it comes first. This means that negation explains how about affirmation situation is. There are three types of negation in languages: 1 . Denial, 2. Rejection, 3. Non-existential. Denial is generally called as Standard Negation (SN), which refers to the negation of simple indicative sentences using an overt verb predicate (Veselinova 2014: 1), as in (a) John does not read a book. Standard negation separates from the rejection as in (b) Mary is not a teacher. And non-existential as in (c) There are no book on the shelves. As you see from the given examples, three types of negation have different strategies that negated by different operators.

\footnotetext{
${ }^{1}$ Corresponding author. Tel.: +1-613-761-7440

E-mail address: muberraseydi@ gmail.com
} 
Existential negation is the main focus of this study. Section 2 gives a general overview about existential negation in languages. Section 3 mentions different types of negation in Turkish and gives related examples. Section 4 bases on existential negation in Turkish and explained what kind of negative existentials are in Turkish. In this section, yok, değil and $-s X z$ are identified as a negative existential item. Besides, section 4 examines for synchronic functional properties of Turkish negative existentials. Section 5 is the conclusion section that summarizes the study and provides comparison of Turkish negative existentials.

\section{Existential Negation in Languages}

Negative existential is one of the classic problems in the philosophy of language. According to Russel's theory, there is a distinction between grammatical form and logical form (see 1903, 1905). This means that sentences express thoughts or propositions. Just as a sentence has a grammatical form, so the proposition (thought) expressed by the sentence as a logical form. Sometimes the logical form of the preposition expressed by $\mathrm{S}$ matches the grammatical form of S, and sometimes it doesn't. The reason for this is the grammatical form is more complex than the logical form, which can't be paraphrased easily. Analysing strategies of these two forms, logical form and grammatical form, work differently and therefore, in this study, I separate the linguistics negation from logical negation and I only examine the strategy of linguistics negation by linguistics ways.

Existential negation occurs utilizing a special strategy in languages since it is excluded from the domain of Standard Negation (SN). There can be different types of negative existentials in languages, but linguistically, they can be categorized. Negative existential is generally used for the common similarity of a structure as morphological, syntactic and semantic typologies. Morphologically, since they have special semantic features, negative existentials are separated from other words and they have their own word class. As they have some verbal properties, morpho-syntactically, negative existentials are used as a predicate in a sentence to eliminate the meaning of existence. Its origin occurs in different ways: 1. Univerbation of SN and another word, 2. Lexical item with negative content, 3. formally identical with SN (origin unknown) (see Croft 1991; Miestemo 2007; Veselinova 2013).

There are some researches about the origins of negative existentials in the literature, but I want to give Veselinova's following chart:

Table 1. Origins of negative existentials

Formally and constructionally different from SN

Negative existentials and SN are formally identical but morphologically different

Negative existentials and SN are formally identical but are used in different constructions

$\mathrm{SN}$ or a negative quantifier alternate for the negation of existence

No special negative existential

Semantically, negative existentials have special meanings associated with diachronic background. Generally, they mean "absent", "lack," "there is not", "poor", "empty", "dead" etc. The most important semantic feature of negative existentials is that they predicate the absence of an entity in a very categorical way rather than negate its existence. This means it is not the opposite of existential categorically. It is the only absence of existence. In other words, negative existentials eliminate the existence of what is presupposed to exist.

Special negative existentials have similarities about their morphological, morphosyntactic, and diachronic background in languages. Although common typological properties, negative existentials have separated semantic characteristics which show a high number of functions. Veselinova separated 
it from negation marker and called its function as "DOMAIN OF ABSENCE" (2013: 139). In that sense, negative existentials are used to say about the absence of something, rather than negate to existence. For this reason, it has a special position cross-linguistically.

What kind of constructions in languages are seen where negative existentials occur? There are some specific types of existentials. Generally, existential and non-existential sentences are used with locativepresentative constructions. According to Hengeveld's (1992) opinion, locative-predication constructions often share features with existential constructions. However, there is a difference between "existential negation" and "locative negation." As a view of Veselinova, sentences which have existential negation or locative negation separated from each other with locative predicate and definite subject:

(1) There are no mice in the basement.

(2) The cat is not on the couch.

The first example above is an existential negation, which refers to the negation strategy used in existential sentences. Second is an example of locative negation that refers to the negative strategy used in sentences with locative predicate and a definite subject. "... If a negative existential is used in locative statements, it will deny the existence of an entity in an absolute, categorical way. No contrast with another entity or another location is possible." (2013: 124).

'Negation of possession/possessive negation' is used to refer to sentences which express negated predicative possession:

(3) Mary doesn't have a car.

Another construction of negative existential is using as short answer "No". In this position, it always interacts with $\mathrm{SN}$ and its properties as tense-aspect-mood category.

\section{Negation in Turkish}

Turkish is a multiple negation language, which has a strict negative concord, weakness negation, emphatic negation, and double negation. All of these negation types are formed with different strategies. There is a 'prototypical difference' in Turkish that provides standard negation with the suffix -mA as in examples below:

(4) a. Sevgi okul-a gel-me-di- $\varnothing$.

Sevgi school-LOC come-SN-PST-3SNG

"Sevgi did not come to school."

b. Öğrenci-ler bugün koş-ma-yacak-lar.

Student-Pl today run-SN-FUT-3PL

"Students will not run today"

c. Akşam yemek ye-mi-yor-um.

Evening food eat-SN-CNV-1SNG

"In the evening, I am not eating the food." 
$-m A$ is the inflectional suffix which is attached to the verb before tense-aspect markers and personal endings. In negation, it is an internal negation operator that can take both narrow and wide scope. Its function is denying the meaning of the verb.

In addition to the standard negation, değil is used in different functions for rejective negation. It is an independent morpheme that can take tense-aspect-mood and personal endings through past copula and evidential copula, and also without copula. It can be used in non-verbal as in 5(a) and some verbal sentences for emphatic negation as in 5(b):

(5) a. Evren mutsuz değil-di-Ø.

Evren unhappy REJ-PSTCOP-3SNG

Evren was not unhappy."

b. Bu yağmur-da yürü-yecek değil-im.

This rain-LOC walk-FUT REJ-1SG

"It is not I will walk in this rain."

In Turkish, $-m A$ and değil are used as negative markers that have different negation functions (for details, see Erguvanlı 1981; Tura 1981; Van Shaaik 1994; Göksel-Kerslake 2006 and Erk Emeksiz 2010).

\section{Existential Negation in Turkish}

In addition to denial and rejection, another category of negation is existential negation, which I focus on in this study. In Turkish, existential negation occurs through the yok, $-s X z$ and değil morphemes. Each of them is used in different positions and have separate functions that I will explain here.

\subsection{Yok}

Free morpheme yok, which means "absolute absence, non-existence" is the general existential negation item in Turkish as seen in the examples below:

(6) a. Okul-da park yok.

School-LOC park NEG.EX

"There is not a park at the school."

b. Ev-de yemek yok-tu.

Home-LOC food NEG.EX-PST

"There was no a food at home."

c. Can ev-de yok-mus.

Canhome-LOC NEG.EX-ASP

"There was no Can at home."

Yok is the most known and used negative existential morpheme in Turkish. It has been using since the Old Turkic times as opposite of the bar var "there is" morpheme (see Ağca 2010). Negative existential yok varies from the ordinary verbal negator $-m A$, and it has particular lexical meaning that associated with its diachronic background. Yok < *yō- "wipe out" + k (nominalization): (Clauson 1972; 895; Erdal 1991: 257; Tekin 2003: 91; Çakmak 2004: 463-471). Erdal maintains that yok "there isn't" 
is a tripartite nominal though mostly used predicatively and it signifies "non-existing" on the other hand, "non-existence" (2004). Furthermore, negative existential yok is found in all modern Turkic languages as negative existential (see Veselinova 2014). It replaces to affirmative existential var, and it tells the absence of indicated meaning as in examples below. It can be used in different conditions and structures. It is generally used with locative predicates.

\section{(7) a. Okul-da park var.}

School-LOC park EX

"There is a park at the school."
b. Okul-da
park yok.
School-LOC park NEG.EX

"There is not a park at the school.

Yok has some verbal properties which admit some tense-aspect markings through copula. This means that negative existential word yok in a predicative position requires the copulas in all contexts except present indicative, which is marked with $\varnothing$. The copulas derive from $i-$, which is a residue of Old Turkic 'be'. However, it is necessary to say that there is grammaticalization about adding copula to nominals and adjectives in today's Turkish. The past copula idi and the evidential copula imis are not generally used with nominals and adjectives in predicative positions. For this reason, tense-aspect markers can be added directly to negative existential yok as in the table below.

Table 2. Inflection rule of Yok

$\overline{Y o k+(\mathrm{i}-)+(\text { tense/aspect markers })+\text { personal endings }}$

Table 3. Inflection examples of Yok

\begin{tabular}{llll}
\hline & Past Simple -DX & Evidential $-\mathbf{m X s ̧}$ & $\begin{array}{l}\text { Present } \\
\varnothing / D I r\end{array}$ \\
\hline 1SG & yok-tu-m $(<$ yok idi-m) & yok-muş-um $(<$ yok imiş-im) & yok-Ø-um \\
2SG & yok-tu-n $(<$ yok idi-n) & yok-muş-sun $(<$ yok imiş-sin $)$ & yok- Øsun \\
3SG & yok-tu (< yok i-di) & yok-muş $(<$ yok imiş $)$ & yok-Ø/ yok-tur \\
1PL & yok-tu-k $(<$ yok idi-k) & yok-muş-uz $(<$ yok imiş-iz $)$ & yok-Ø-uz \\
2PL & yok-tu-nuz (yok idi-niz) & yok-muş-sunuz $(<$ yok-umuş-sunuz) & yok-Ø-sunuz \\
3PL & yok-tu-(lar) $(<$ yok idi-(ler $))$ & yok-muş-(lar $)(<$ yok imiş-(ler $))$ & yok-(lar $)^{2}$ \\
\hline
\end{tabular}

Besides of past copula and evidential copula, some converbs and conjunctions derive with $i$ - (iken and ise), but these can be added directly to yok:

(8) Sen yok-ken bütün kitap-lar-l oku-du-m.

You NEG.EX-CONV whole book-PL-ACC read-PST-1SG

"I read all books while you were away."

(9) Mehmet yok-sa toplant yap-a-ma-yzz.

Mehmet NEG.EX-COND meeting make-ABIL-SN-1PL

"If there is not Mehmet, we can not make a meeting."

In Turkish, yok is the example of multifunctional negative existential. It is generally used in the negation of presupposed existence as seen in the above examples and also possession and locative constructions. In addition, it can be in other positions with absence function. It is used as the general

2 The using of 3. plural personal ending is optional. If the subject plural, the plural form of the personal ending $-I A r$ can be used, but the singular form (without -IAr) is preferable." 
word for "no" or the short answer for "no". It may also be used as an emphatic negator in negative sentences. Moreover, it can be used in the double negation for cancelling the negative meaning of the sentence. Finally, it is used as in emphasized standard negation in prohibitive situations. I will explain how all these positions are seen in Turkish.

Possessive negation tells another non-existence position in the negation. In Turkish, possession case occurs by affirmative item var and non-possession occurs by negative item yok. ${ }^{3}$ In the following examples yok describes the absence of possession.

\begin{tabular}{|c|c|c|}
\hline (10) a. Zaman'ın & $a r a b a-s ı$ & var. \\
\hline $\begin{array}{l}\text { Zaman-GEN } \\
\text { "Zaman has }\end{array}$ & $\begin{array}{l}\text { car-3.SG } \\
\text { ar." }\end{array}$ & EX \\
\hline $\begin{array}{l}\text { b. Zaman'ın } \\
\text { Zaman-GEN }\end{array}$ & $\begin{array}{l}\text { araba-sl } \\
\text { car-3SG }\end{array}$ & $\begin{array}{l}\text { yok. } \\
\text { NEG.EX }\end{array}$ \\
\hline \multicolumn{3}{|c|}{ "Zaman hasnt got a car." } \\
\hline $\begin{aligned} \text { (11) a. } & \text { Kedi-m } \\
& \text { cat-1SG } \\
& \text { "I have g }\end{aligned}$ & $\begin{array}{l}\text { var. } \\
\text { EX } \\
\text { t.." }\end{array}$ & \\
\hline b. Kedi-m y & & \\
\hline $\begin{array}{l}\text { Cat-1SG } \\
\text { "I haven't go }\end{array}$ & & \\
\hline
\end{tabular}

Short answer "no": Yes/No questions are generally replied with evet and hayır in Turkish. It is necessary to say that the NO word hayır is a lexical copy from Arabic. Before it was copied, negative existential word yok was used as NO answer. Therefore, yok continues to express the NO answer in today's Turkish as you see in the short answer below. It refers to negative meaning of the whole sentence. By this way, yok implies that the action pointed to in the question has not taken place. At this point, there is a reference to an indirect absence.

(12) Ahmet ev-e gel-di mi?

Ahmet home-DAT come-PST QM

"Did Ahmet come to the home?"

-Yok.

NEG.EX

"No."

$(\rightarrow$ (Haylr) Ahmet ev-e gel-me-di. $)$

(No) Ahmet home-DAT come-SN-PST

"(No) Ahmet did not come to the home."

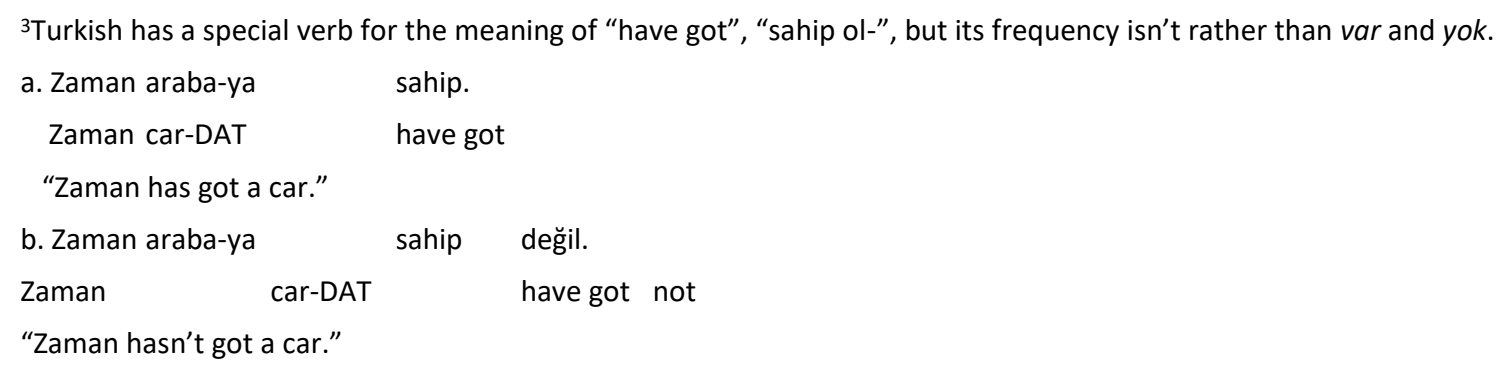


Yok is used as an emphatic negator item with another NO word hayır in the same sentence.

$\begin{array}{llll}\text { Yemek } & \text { ye-di-n } & \text { mi? } & \\ \text { Dinner } & \text { eat-PST-2SG } & \text { QM } & \\ \text { "Did you eat dinner?" } & & \\ \text {-Hayrr, yok. } \quad \text { Mok, } & \text { hayır. } \\ \text { No, NEG.EX } \quad \text { NEG.EX } & \text { No } \\ \text { "No, no." } & \\ (\rightarrow \text { Yok, ye-me-di-m.) } & \\ \text { No, eat-SN-PST-1SG } & \\ \text { "No, I did not eat." }\end{array}$

Word order of yok in the sentence is variable, as seen in the examples above. The semantic of these two structures do not have a different meaning. Hayır and yok can easily be used instead of each other for emphatic negation. Using these two negative items together is to strengthen the negation meaning.

Croft (1991) submitted negative existentials as another source of markers for verbal negation. Negative existential item yok is used for standard negation semantic by emphasizing the meaning of denial in some constructions:

(14) Okul-a

$$
\text { git-tiğ-i yok. }
$$

School-DAT go-PRTC-3SG NEG.EX

"There is no that he is going to school."/ "He is not going to the school."

$(\rightarrow$ Okul-a git-mi-yor. $)$

School-DAT go-SN-PRC

"It is not the case that He is not going to the school."

The example above has a complex structure because of its specific strategy. Normally, it is not necessary to pronounce such a sentence in Turkish, because it is not common usage in daily language. It is formal, but it has less frequency. It has a special pragmatic background. It is observed that the speaker wants to say a specific case in an indirect way. Speaker thinks this way is most effective than the standard negation way. Well, why this way is the most effective than the other? The reason for this is negative existential has absolute priority to another negation strategies as denial or rejection. Logically, absence of absence is not possible. Because of this, yok refers to the non-existence position of action's meaning with a special strategy. Moreover, the opposite meaning of this sentence has not occurred with the existential word var. If var is used in this sentence, the structure is ungrammatical:

(15) * Okul-a

\section{School-DAT}

git-tiğ-i var.

go-PRTC-3SG EX

In the above example, yok is used for emphasizing the "deny" meaning of the sentence. Namely, emphasized denial is expressed by yok in combination with participial/ nominalized form of the verb and the subject marked by the genitive case as in $(16)^{4}$.

\footnotetext{
${ }^{4}$ According to the given example by van Schaaik as in below, Veselinova mentioned yok as it is expressed for emphatic negation (2016). I need to point that "emphatic negation" is the different type of negation in negation literature. It belongs to "multiple negation" and it needs two negative elements in the sentence. In these sentences, one of the negative elements strengthens the other semantically. In that, two negative elements coexist and continue semantic negativity by not canceling each other (see Wouden 1997 and Zeijlstra 2004b).
} 
The same structure can be seen in the use of different participle, $-(y) A c A k$ :

(16) Bu çocuğ-un ödev yap-acağ-ı yok.

This child-GEN homework do-PRTC-3SG NEG.EX

"It is not that this child will do his homework."/ "This child will not do his homework."

$(\rightarrow B u \quad$ çocuk ödev yap-ma-yacak.)

This child homework do-SN-FUT

"This child will not do his homework"

Syntactically, $-D I K$ and $-(y) A c A K$ are used as multifunctional subordinating suffixes. When the participles $-D I K$ and $-(y) A c A K$ cooccur with yok, $(-D I K+y o k$ and $-(y) A c A K+y o k)$, yok negates the referring of these participles. They have the same feature, which do not accept the var morpheme. Otherwise, an ungrammatical structure emerges.

In some examples like given below, the negative existential yok is used for a specific prohibition case. It is used after the infinitive. It indicates the fact that the meaning of the verb should not happen. It is a periphrastic and peripheral usage in formal daily language. It is generally used for kids to prohibit actions which are said in the sentence. It can be said that these examples are for children language. Additionally, negative existential has a very important role in children language. Children firstly learn negative existentials as a negation item. Then, they learn SN item, and they start to use it (see Horn 2001). Therefore, given examples are used only for children for prohibitive purposes. Besides, they are also used by children to negate the verbal.

(17) Okul-a

$$
\text { git-mek yok. }
$$

School-LOC go-INF

NEG.EX

"No going to the school."

(18) Park-ta koş-mak yok.

Park-LOC run-INF NEG.EX

"No running at the park."

In both cases, the meaning of sentences above in the space of imperative. However, there is a pragmatic difference between formal imperative and this structure. The first example below is a formal imperative sentence in Turkish. It occurs with SN marker - $m A$ in negative imperative structure. Another example that I'm talking about occurs with negative existential yok and it is generally used for children. It has polite meaning than the formal imperative meaning. This is to say that the sentence is not an example of an imperative structure; it is only the sentence of prohibition structure.

(19) Park-ta koş-ma.

Park-LOC run-NEG-IMP

"Don't run at the park."

(20) Park-ta koş-mak yok.

Park-LOC run-INF NEG.EX

"No running at the park."

Negative existential yok and SN marker $-m A$ can be used together in double negation structure. However, in this type of structure, the meaning of the sentence is affirmative. As it is called "Double

\begin{tabular}{lll}
\hline Kadın-ın Ali-ye & bak-tı̆̆-ı yok-tu. \\
Woman-GEN Ali-DAT & look-PRTC-3SG NEG-EX-PST
\end{tabular}

"No woman didn't look at Ali at all."/ lit. "There was no woman's-to-Ali-looking." (van Schaaik 1994:46) 
Negation" in the literature (see van der Wouden 1997; Zeijlstra 2002; Zeijlstra 2004a), if two negation items co-occur, they cancel each other and by this way semantic of the sentence becomes affirmative.

(21) Bil-me-diğ-i yok.

Know-SN-PRTC-3SNG NEG.EX

"There is nothing s/he does not know."

Double negation is used for providing the affirmative meaning of a sentence. According to some scholars, this is because the speaker wants to enhance affirmation by double negation rather than saying the affirmation by the simple way (see Horn 2001: 119; Krifka 2007: 2). As it is seen example above, the meaning of the sentence enhanced its affirmation through two negative items. In fact, there is an exaggeration semantic in this sentence:

(22) Bil-me-diğ-i

yok.

Know-SN-PRTC-3SNG NEG.EX

"There is nothing s/he does not know." (Exaggeration meaning is that "He knows everything!")

Considering studies about double negation, two negative items cancel each other. Logically, it is possible to say this but, semantically it must be a strong negative item for canceling another negative item. The example above negative existential word yok is stronger than standard negation marker -me. Moreover, the semantic properties of negative existential items confirmed that non-existence is stronger than non-being. Therefore, the exaggeration meaning comes to exist through the cancellation of the meaning of standard negator - $m e$ by negative existential item yok.

\section{2. $-s X z$}

$-s X z$ is the dependent morpheme which is attached to nominals by "without" meaning. It is generally used as an adjectival suffix. It describes "lack" whatever expressed by the root: sinir-siz "unlimited", para-siz "free of charge", on-suz "without him" etc. (see Göksel\&Kerslake 2006). Actually, the semantic of lack and non-existence are different (see the diagram below and see for also information Krifka 2007). Lack is between the non-existence and existence positions, but in some cases, $-s X z$ can be used instead of $y o k$ as absence position and yok can be used instead of $-s X z$ as lack position.

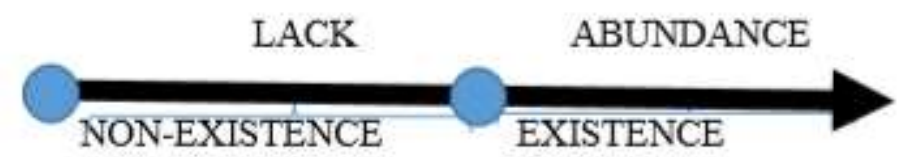

Figure 1. Line error for existentiality

(23) Yemek tuz-suz.

Food salt-LACK

"The meal is unsalted."

$(\rightarrow$ Yemek tuz-lu.)

Food salt-ADJ

"The food is salty."

(24) Yemeğ-in tuz-u yok.

Food-GEN salt-AC NEG.EX

"There is no salt in the food."

$(\rightarrow$ Yemeğ-in tuz-u var.) 
Food-GEN salt-ACC EX

"There is salt in the food."

The functions of $-s X z$ are to tell the lack of existence and to point to the grading in this respect. For example, the first example above means that "The food is unsalted." How can we explain this sentence in lack of existence context? According to the semantic frame, there is some salt in the food, but it is not enough; it is deficient. Therefore, the speaker says this deficiency by using $-s X z$ morpheme. However, using the $-s X z$ implies a non-existence case. Besides, the second example means that "There is no salt in the food." It is impossible to grade non-existence. There is no lack of non-existence or abundance of non-existence. Non-existence is only non-existence. Nevertheless, in the usual Turkish, these two items may be used as the same semantic purpose without any specific information.

As a result, $-s X z$ is accepted as negative existential item since it also implies the non-existence while it describes the lack.

\subsection{Değgil}

Değil, "is not" is generally used as rejection item, but in some cases as the example below, değil is used as another negative existential in non-existence position. It is an example of a locative negation that has a definite subject.

\section{(25) Can ev-de değil.}

\section{Can home-LOC NEG-REJ}

"Can is not at home."

$(\rightarrow$ Can $\quad e v-d e$. $)$

Can home-LOC

"Can is at home."

In Turkish speaker can use yok in the same sentence as below, but it needs to said that even if they have the same semantics, there are pragmatic differences between two sentences.

(26) Can ev-de yok.

Can home-LOC NEG.EX

"There is not Can at home."

$(\rightarrow$ Can evde.)

Can home-LOC

"Can is at home."

Examples above are related to different types of existential negation. Speaker wants to give information about Can's situation that he is not at home. As it is shown, there are two different ways of saying this meaning. In the first example, the morpheme değil is used for rejecting the existence meaning of "Can evde". It implies non-existentiality. The second example occurs with another morpheme yok that does not reject the affirmative meaning. It tells the absence of somebody or something; There is no Can at home. It is like There is no sugar in the bowl.

As you see, değil and yok separated from each other. The particle değil is used to negate locative predications. According to the Shaaik, the negative existential yok may be used for their negation only in very special cases (1994: 41-45). Therefore, while değil is the rejection item, yok is the negative existential item. The affirmative counterparts of these two sentences are the same: Can evde. Değil and yok negate the sentence of Can evde., but they have different functions because of their pragmatic 
backgrounds. To say the first sentence, the speaker wants to refuse given information about Can is at home. By this way, the speaker gives indirect information about non-existence case. For the second example, the speaker has specific information about Can's absence at home. He tells the truth of nonexistence case with yok.

Negative existential yok is excluded from the constructions of contrastive focus, and the rejection item değil is used instead. This is an obligatory optional construction in discourse because of the information structure.

\section{Conclusions}

The semantic value of existential negation varies according to the morphological and morphosyntactic properties of negative existential items. In Turkish, yok is the main negative existential item which generally replaces the positive counterpart var. It is different from the verbal negation, and it is a separate lexical item with negative content. It is formally and constructionally different from SN. The exclusive structures which yok is used and pragmatic background of sentences interchange yok's functions, and by this way, yok has different semantic functions. Since yok is the part of the existential negation with the meaning of "absence", it is a powerful negation item. Due to its strong property in negation, it can easily be used in different positions with different negation items. Besides, it is necessary to state that since it is an archaic morpheme with "absence" meaning, it has a tendency to still exist in positions it has been in before. Therefore, yok easily substitutes the words, as değil and haylr copied to Turkish in the later periods of Turkish and yok fulfills their functions.

Besides the yok, the privative bound morpheme $-s X z$ is used as privative with "lack" meaning by referring the non-existence case. Although yok and $-s X z$ have different semantics, yok is used instead of $-s X z$ without any semantic differences in daily Turkish. Moreover, the "lack" meaning of $-s X z$ implies non-existentiality about something that is referred. In that, "lack" signs the "absence of something" at the same time.

Also, general rejection item değil implies the non-existentiality by refusing the affirmation case. The function of değil is implying the non-existentiality by rejecting the existence case that is presupposed. In given examples, değil is used as the example of locative negation, which has a locative predicate and a definite subject. Yok can be used in the same position, but there is a pragmatic difference in these two types because of the information structure. Therefore, in Turkish existential negation, değil is used for a special purpose by rejecting the existence case and in this way, it refers the non-existence.

Consequently, while yok is the most effective direct negative existential with "absolute absence" meaning, $-s X z$ and değil are indirect negative existentials in Turkish.

Briefly, positions of Turkish negative existentials and examples follow:

Table 4. Functions of Turkish negative existentials

\begin{tabular}{lll}
\hline yok & Function & Example \\
Existential negation & Okul-da park yok. \\
& School-LOC park NEG.EX \\
& "There isn't a park at school." \\
& Zaman'in araba-st yok. \\
& Zaman-GEN car-3SG NEG.EX \\
Possessive negation & "Zaman hasn't got a car." \\
& -Ahmet ev-e gel-di mi? \\
& Ahmet home-DAT come-PST QM \\
Short answer "no" & "Did Ahmet come to the home?" \\
& - Yok. \\
\hline
\end{tabular}




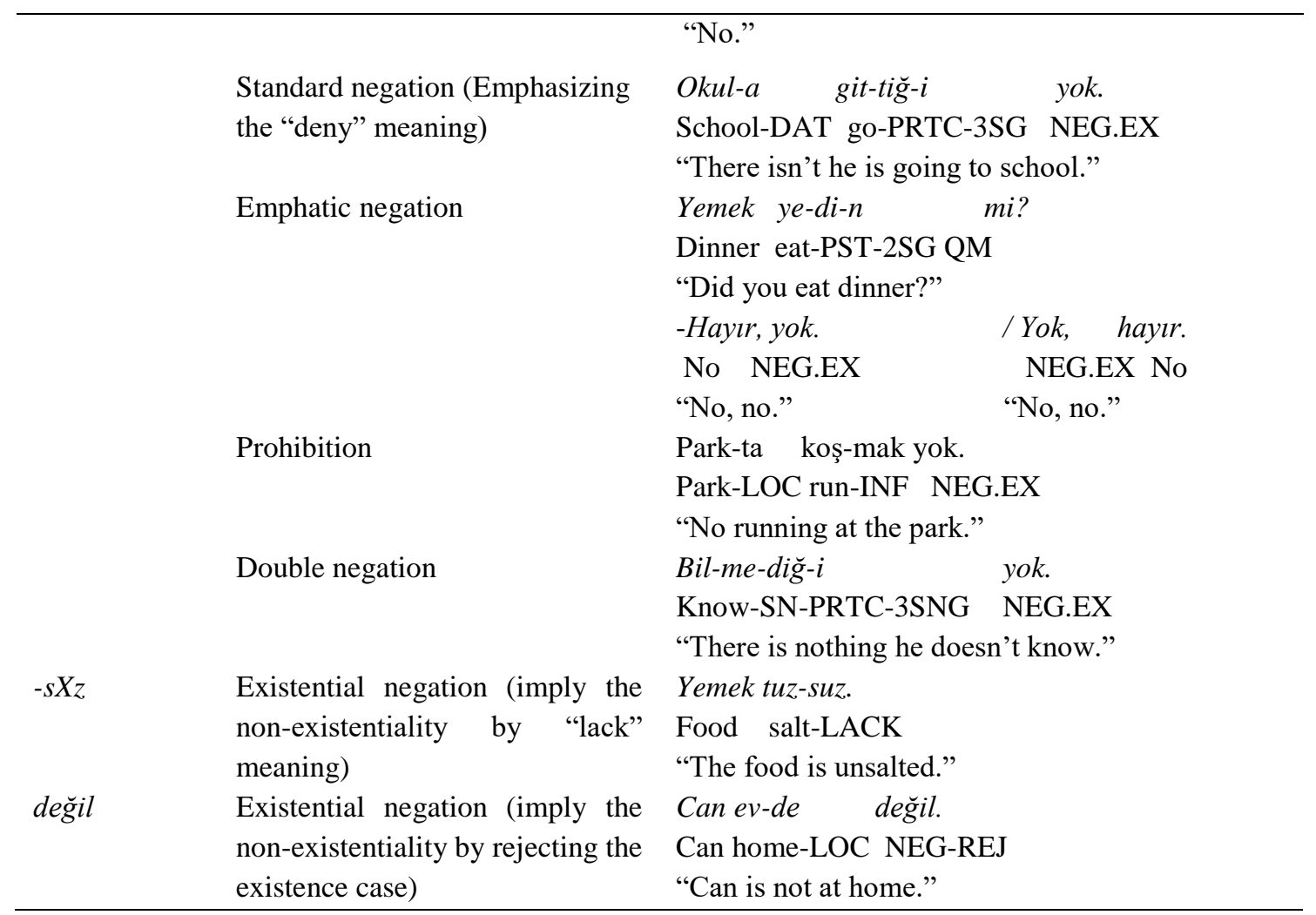

\section{Ethics Committee Approval}

The author(s) confirm(s) that the study does not need ethics committee approval according to the research integrity rules in their country (Date of Confirmation: June 02, 2020).

\section{References}

Ağca, F. (2015). Eski Türkçede Varlık ve Yokluk İşaretleyicileri. Dil Araştırmaları, 16: 83-101.

Çakmak, S. (2013). "Var” ve "Yok" Sözcüklerinin Morfolojik Kimliği. Turkish Studies, 8/4: 463-471.

Clauson, G. (1972). An Etymological Dictionary of Pre-Thirteenth-Century Turkish. Oxford.

Croft, W. (1991). The Evolution of Negation. Journal of Linguistics, 27: 1-39.

Erdal, M. (1991). Old Turkic Word Formation. Leiden: Brill.

Erdal, M. (2004). A Grammar of Old Turkic. Leiden: Brill.

Erguvanl1,T. E. (1984). Some Aspects of Negation in Turkish. In Proceedings of the Turkish Linguistics Conference, Aksu-Koç, A. and E. Erguvanl1-Taylan (eds). İstanbul: Bogaziçi Publications.

Hengeveld, K. (1992). Non-verbal Predicability. In Meaning and Grammar: Cross-Linguistic Perspectives. Michel Kefer \& Johan van der Auwera (eds). Berlin: Mouton de Gruyter.

Erk Emeksiz, Z. (2010). Negation in Turkish. Dilbilim Araştırmaları, 2, 1-15.

Horn, Laurance, R. (2001). A Natural History of Negation. Stanford: CSLI Publications.

Kerslake, C. \& Göksel. A. (2005). Turkish: A Comparative Grammar. London: Routledge. 
Krifka, M. (1995). The Semantics and Pragmatics of Polarity Items. Linguistic Analysis, 25, 209-257.

Krifka, M. (2007). Negated Antonyms: Creating and Filling the Gap. In Uli Sauerland and Penka Stateva (Eds.), Presupposition and implicature in compositional semantics. Palgrave Studies in Pragmatics, Language and Cognition. (pp.163-177). Palgrave Macmillan.

Miestemo, M. (2007). Negation- An Overview of Typological Research. Language and Linguistics Compass, 1(5), 552-570.

Russel, B. (1903). The Principles of Mathematics. United Kingdom: Cambridge University Press.

Russel, B. (1905). On Denoting. Mind, 14,479-93.

Tekin, T. (2003). Orhon Türkçesi Grameri. İstanbul: Kitap Matbaası.

Tekin, T. (2009). Orhon Yazıtları. Ankara: TDK.

Tura, S. (1981). A study on negation in Turkish. (Unpublished doctoral dissertation). Middle East Technical University, Ankara.

Van Shaaik, G. (1994). Turkish. In K. Peter \& R. van der Berg (Eds.), Typological Studies in Negation. (pp. 35-50). Amsterdam: John Benjamins Publishing Company.

Veselinova, L. (2013). Negation in Existential Sentences: A Cross-Linguistic Study. In Delia Bentley, Francesco Maria Ciconte and Silvio Cruschina (eds.) [Special issue] Italian Journal of Linguistics, 25(1),107-145.

Veselinova, L. (2014). Negative Existential Cycle Revisited. Linguistics, 52(6),1327-1389.

Van der Wouden, T. (1997). Negative Contexts: Collocation, polarity and multiple negation. London: Routledge.

Zeijlstra, H. Hedde. (2002). What the Jespersen's Cycle May Reveal about Negative Concord. Linguistics in Potsdam, 19,183-206.

Zeijlstra, H., Hedde. (2004a). Two Ways of Expressing Negation. Proceeding of ConSOLE, 12, 245259.

Zeijlstra, H., Hedde. (2004b). Sentential Negation and Negative Concord. Netherlands: LOT.

\section{Appendix A. Abbreviations}

$\begin{array}{lllll}\text { ABIL } & \text { ability } & \text { AC } & \text { accusative } & \text { ADJ adjective } \\ \text { ASP } & \text { aspect } & \text { CV } & \text { converb } & \text { DAT dative } \\ \text { EX } & \text { existential } & \text { FUT future } & \text { GEN genitif } \\ \text { GER } & \text { gerund } & \text { INF } & \text { infinitive } & \text { IMP imperative } \\ \text { LOC } & \text { locative } & \text { NEG } & \text { negation } & \text { NEG.EX negative existential } \\ \text { PE } & \text { personal ending } & \text { PL } & \text { plural } & \text { PRC present continuous } \\ \text { PRTC } & \text { participle } & \text { PST past } & \text { QM question marker } \\ \text { REJ } & \text { rejection } & \text { SG } & \text { singular } & \text { SN standard negation }\end{array}$




\section{Türkçede varoluşsal olumsuzluk: İşlevsel bir yaklaşım}

\section{$\ddot{O} \mathbf{z}$}

Dillerde görülen varoluşsal olumsuzluk, ögesi "varoluşsal olumsuzluk ögesi” olarak adlandırılan ve "yokluk", "yoksunluk", "var olmama", "fakir", "boş”, "ölü” durumlarını anlatmayı sağlayan bir olumsuzluk türüdür. Varoluşsal olumsuzluk ögeleri genellikle ortak morfolojik, sentaktik ve semantik tipolojilerde kullanılır. Türkçede varouşsal olumsuzluk, "kesin yokluk/ varolmama" olarak tanımlanan bağımsız biçimbirim yok ile gerçekleştirilmektedir. Yok, standard olumsuzluktan farklı, olumsuzluk içerikli ayrı bir leksikal öge olarak temel varouşsal olumsuzluk ögesidir. "Kesin yokluk/ varolmama" anlamıyla oldukça güçlü bir olumsuzluk ögesi olduğundan varoluşsal olumsuzluk, sahiplik olumsuzluğu, pekiştirilmiş olumsuzluk, standard olumsuzluk, kısa cevap "hayır", yasaklama ve çift olumsuzluk gibi farklı pozisyonlarda kullanılabilmektedir. Yok'a ek olarak, "yoksunluk" anlamıyla bağımlı biçimbirim $-s X z$, varoluşsal olumsuzlukta varolmamayı ima ederek kullanılır. Ayrıca genel reddetme ögesi değil, varoluşsal olumsuzukta önesürülen varoluş durumunu reddetme yoluyla varoluşsal olumsuzluğu ima ederek kullanılır.

Anahtar sözcükler: varoluşsal olumsuzluk; türkçe varoluşsal olumsuzluk ögeleri; yok; -sXz; değil

\section{AUTHOR BIODATA}

Muberra Seydi works as a Turkish Instructor and Turkish Tester in Canada. 